\title{
ONLINE METACOGNITIVE TASKS FOR EFL DISTANCE LEARNERS
}

\author{
Assoc. Prof. Dr. Soraya GARCIA-SANCHEZ \\ Department of Modern Languages \\ Universidad de Las Palmas de Gran Canaria \\ Las Palmas de Gran Canaria, Spain
}

\section{ABSTRACT}

Online courses have benefited from the adequate use of digital resources that allow learners to be the center of their own learning process. More often online instructors not only aim at what students have to individually do but learners are also engaged in interacting with the educational community by means of a variety of metacognitive activities, which can be planned, thought and accomplished anywhere and at any time (ubiquitous learning). This article proposes a debate on the awareness of strategic knowledge acquisition to particular situations providing interactive scenarios among students of English as a Foreign Language (EFL) in online courses. Without communicative activities, the successful production of any foreign language is not complete since knowledge building and the understanding of the foreign language, either in written or spoken form, are the key points of an adequate performance of communication. The findings of this study will provide information about useful online tasks for the adequate performance of communicative metacognitive skills required in an EFL language distance course. Finally, some future research paths inclined to improve EFL distance learners from a metacognitive and ICT-based collaborative perspective are also suggested.

Keywords: Autonomous learning, communication, distance learning, EFL, u-learning.

\section{INTRODUCTION}

Nowadays, online instructors are regularly revising their programs and assessment criteria to adapt them to student feedback as well as changes in emerging technologies. This contextualized adaptation also aims at responding to learners' needs so that the online learning community can provide the resources and the learning scenarios for the successful performance of competences. The use of appropriate technology in online courses is important for improving both learning and the relationship between students and teachers when creating and sharing knowledge (Spector, 2014). Online distance learners can benefit from a proper selection of ubiquitous learning (u-learning) tools that allow participants the flexibility and creativity to complete the required tasks at the best time and in the best place they choose to access their courses. The physical space of a traditional classroom is transformed into a variety of digital spaces by means of internet access and the use of $u$ learning technologies.

It is doubtless that technologies can offer opportunities to modify instruction, to transform assessment and to enhance online learning. Since analyzing students' metacognitive performance and communicative skills in English as a Foreign Language (EFL) is the main goal of this article, a review of the literature on current pedagogical strategies that are suitable for online courses will be presented in the first part of this chapter. The interactive tasks necessary for attaining communicative language competences will be addressed in the second half of this paper. Next, examples of online tasks used with the intention of encouraging active participation in EFL online courses will be revealed. Finally, the results emerging from the combination of the communicative language skills in EFL with the formative assessment designed for these online courses will be discussed. 
This case study is based on a compulsory subject of EFL in the distance learning Degree in Social Work at the Universidad de Las Palmas de Gran Canaria (ULPGC) in Spain. The main objective of this chapter is to demonstrate that a careful design of interactive tasks and assessment criteria will support u-learning distance learners in the conscious production of their EFL knowledge and communication.

\section{BACKGROUND}

\section{Current EFL Pedagogical Strategies}

It is a regular practice to see today's learners using mobile devices such as laptops, tablets or smart mobile phones to, first, find any necessary information instantly, and, second, to access lecture videos, digital documents, interactive or downloadable activities and discussion forums posted on course platforms and social networks (Burbules, 2012; GarciaSanchez, Guerra-Artal \& Afonso-Suarez, 2012). While the former action participates in informal learning, the second connects learners with a formal learning environment. Both behaviors often entail the approval of technology in education (Imtiaz \& Maarop, 2014). Both would constantly improve present citizens' knowledge and critical thinking.

Currently, a variety of pedagogies that focus on a participatory communicative approach in EFL has been necessarily implemented in the foreign language classroom (Andersen \& Ponti, 2014; Cancino, 2015). Adair-Hauck and Troyan (2013) have even depicted interpersonal modes of communication at the time of dealing with the importance of feedback by means of the Integrated Performance Assessment (IPA). Equally, ubiquitous personalized learning is another strategy that emphasizes the importance of responding to the different type of learner, so that a diverse learning setting is considered (Chen, Lee \& Chen 2005; Taraghi, 2012). Therefore, when delivering online courses, there is a more frequent need to offer interactive learning environments (ILE) that correspond with the reality of their online participants, who may need not only to exchange messages but they may also have the possibility of cooperating and/or collaborating in their knowledge building using digital tools.

A ubiquitous learning environment (ULE) not only allows for flexibility at the time of accessing u-resources but these u-learning materials are also designed to answer students' needs and, consequently, they aim to become context-aware. U-learning happens anywhere else than the classroom. Technology has augmented this extended location, which is more open and no limited to unique situations happening in educational walls (Jones, Chew \& Blackey, 2014). Different scholars have suggested that two remarkable differences between e-learning and u-learning is that knowledge is context-aware and it is accessed anywhere and at any time from any mobile devices that have an internet connection (Liu \& Hwang, 2009; Liu, et al., 2014; Ogata \& Uosaki, 2012). With a ULE, learners are able to constantly access, select and contrast information, as well as interact and share knowledge with others, which benefits their autonomous and collaborative ulearning (Garcia-Sanchez, 2014; Price \& Rogers, 2004). Moreover, it is common to mention a more current terminology for the web 4.0 since its ubiquitous characteristics encourage the educative community to be hyper connected with changing technologies that focus on interaction and intercommunication (Garcia Aretio, 2014; Vizoso Martin, 2013: 243).

Since the focal point of this research is to observe students' EFL interaction in online courses, it is paramount to apply a communicative approach that deals with successfully communicating and understanding messages so that learners are able to improve their communicative competence, and provide thoughtful arguments. This proposes being successfully able to use the foreign language words and rules; its appropriacy; its cohesion and coherence and its accurate use of communication strategies (Canale \& Swain, 1980).

The design of the subject of this study, English Applied to Social Work (EASW), has been planned having in mind the communicative language skills that correspond with the correct written and oral expressions, and with the appropriate structures used when 
communicating meaningful messages in the foreign language. Although this subject is based on English for Specific Purposes (ESP), it involves the use of English as a Foreign Language (EFL) approaches with a variety of technologies that aim to enhance language skills (Traore \& Kyei-Blankson, 2011). Pirsl, Popovska and Pirsl (2013) argued that "ESP is essentially a training operation which seeks to provide learners with restricted competence to enable them to cope with certain clearly defined tasks" (p. 2). The ESP approach allows these future professionals of the field of Social Work to improve the specific communicative tasks designed for their profession but, at the same time, the approach establishes a dialogue with the general communicative language skills in English that students need to improve and demonstrate to succeed in the general communication of the foreign language. Consequently, the teaching material of EASW combines all-purpose foreign language skills with the ESP context of the area of social work in order to respond to these learners' needs (Hutchinson \& Water, 1987).

\section{U-learning Metacognition for Online Interaction}

In order to engage learners in distance interactive learning environments (ILE), an appropriate online system with a correct methodology needs to be applied so that interaction can happen between the learner and the system or among the members of the educational community, that is between learners, and between the learners and the teacher (Garcia Aretio, 2014; Pennings et al., 2014; Psotka, 2012). Suitable tools must be selected and satisfactory learning tasks should be designed by following both an ILE and communicative skills in EFL.

Research by Pirsl, Popovska and Pirsl (2013) suggests that "Metacognition is cognition about cognition or thinking about thinking. Thinking can be about what the person knows and what the person is currently doing" (p. 4). If this definition is considered, a distance learning course should combine both metacognitive abilities with metacognitive experiences. There is no doubt that distance learners are especially put into contexts that require their conscious independent thinking to solve problems. They need to demonstrate a thorough response to their autonomous abilities not only to learn but also to plan, organize and distribute their time and tasks (Martin-Santana \& Garcia-Sanchez, 2014). Metacognitive activities involve active participation by learners and active monitoring by teachers in order to achieve both cognitive and communicative goals (Price \& Rogers, 2004).

The interactive learning approaches applied in this study are based on Task-Based Language Learning (TBLL), Presentation Practice Production (PPP) and Project Based Learning ( $\mathrm{PBL}$ ). Although these practices can be a challenge when participating in online courses, they are focused on improving both cognitive and social skills, which can be either individually-oriented or cooperatively-oriented. TBLL is per se a communicative variety of the communicative learning approach since learners are structured in smaller groups in order to achieve various collaborative goals that require the correct use of the target language (Ellis, 2003). PPP is not a method but a pedagogical strategy (Criado, 2013; Harmer, 1996; Harmer, 2009) that implies communicating the second language by allowing students to create a context that may facilitate the production of the targeted language once the presentation and the practice of the new vocabulary has been delivered in the course. PPT is not new but the use of technology modifies the delivery of this instructive strategy in multiple ways. PBL also implies having small groups working collaboratively and dependently to finally achieve a goal, which may be a solution to a problem or to a question. The main difference, however, between TBLL and PBL is that the latter requires a longer period of time for learners to investigate and to formulate the answers to the project they are creating, while TBLL may be solved in a two-hour session, for instance. 


\section{METHODOLOGY}

This case study results from two academic years of revision and research of the online course, English Applied to Social Work (EASW), as part of the Degree in Social Work in the Distance Learning Platform, Teleformación, at Universidad de Las Palmas de Gran Canaria (ULPGC), Spain. A descriptive qualitative approach was used as part of this case study to consider the learning task and the foreign language skills achieved by students. Furthermore, a digital u-learning approach was adopted in order to collect data from September 2012 to July 2014. These data were mostly gathered from a nonparticipant observation of all the activities and interactive exercises generated on the course platform.

EASW was delivered in the third year of the Degree in Social Work. The average number of students was $\mathbf{4 0}$ students each year. They resided in a variety of places in Spain. The majority were adults whose age was over 30 years old $(70 \%)$. The design of this online course was planned using the Teleformación platform, which is based on Moodle. There were clear aims, exercise, deadlines and assessment criteria for learners to be accomplished at the end of each task and, correspondingly, at the end of the course.

\section{The Learning Environment}

Students in this study participated in a u-learning environment (ULE) that allowed them the flexibility of accessing course materials anywhere and at any time (Kalantzis \& Cope, 2012; Wurst, Smarkola \& Gaffney, 2008). In other words, the participants were afforded the use of context-aware methodologies that were adapted to their needs (Cope \& Kalantzis, 2010; Chenol Mora, 2013; De la Torre et al., 2013; Garcia-Sanchez, 2012). A group forum for discussion, a course chat, YouTube video presentations, and the private tutorial conversations were the main online interactive tools used to promote learners' expression in English.

For the learning plan, distance learners were aware of receiving independent learning input by accessing the textbook, which was designed and published for this purpose. They not only had the textbook in their hands, once they enrolled in this course, but they could also access the e-document all over again from their mobile devices, if they wanted to browse the course material online. Not only the book content but, equally important, the compulsory online tasks, the course forums, video lectures, PowerPoint or Screencast presentations, general feedback on common mistakes and good practice, individual feedback, the private online tutorial and the further practice links posted on the platform were the online u-learning resources that complemented this learning plan. Output was presented by means of learners' participation in the course forums, the glossary, the online tasks they individually had to post on the platform, and the final exam.

The structure of the book was imperative for learners to achieve the learning outcomes. The six learning units that shaped this course were structured in titles, linked to a successful performance for social workers. Each unit had two reading texts and exercises (comprehension and lexis), a use of English section and a vocabulary section with the answer keys for all the activities suggested. The answers were deliberately given in order to promote independent learning skills in these distance learning participants. The topics presented in each of the six units dealt with some aspects of the communication process. The first unit introduced the different characteristics of the communicative process and it established some differences between verbal and non-verbal communication. The consequent four units of the course were more specific for the field of social work and they linked the general concept of communication with human services, family communication, child protection, and elderly people. Finally, there was a last unit devoted to managing communication in prisons. There was also a list of keywords organized at the end of each unit together with a conscious learning grid to allow learners to reflect upon their own learning process. The keys to all the exercises designed in each unit were also included in the textbook. 


\section{FINDINGS}

Interactive Learning: Examples

First of all, the discussion forum in the distance learning course of EASW was proved to be a successful interactive learning tool with three varieties. The first forum, administered by the teacher, functioned as an indispensable notice board since it was devoted to posting news regarding the course. Each time a new topic was posted, learners automatically received the message on their institutional emails. No learners could open a new topic nor reply to any comments posted by the teacher. In this line, some of the messages, especially those that summarized the four face-to-face teaching sessions were often written in Spanish to make sure that students understood the core content of those key meetings. The second forum (see Figure1) was a discussion forum medium and English was the communicating tool used by the participating community. Although both the teacher and the students could open discursive topics, not so many students engaged in this step but just followed the proposals provided by the instructor $(48 \%)$. The last forum was designed as a repository of group questions related to the course program or to the instructions of any specific task, for instance. Some learners preferred to post their questions on the course platform so that they could receive an answer from any other learner or from the teacher $(68 \%)$. Other learners, on the contrary, chose to be reserved on their public contributions. They opted to use a more individual learning approach when using the tool of the private tutorial to directly ask the teacher any questions or seek clarification for any doubts they may have during the course (32\%).

Dear students,

This forum is optional and only opened for you to actively participate in the discussions proposed by your teacher. Be an active contributor so that you can practice your English expression. Remember to use polite language and always be respectful with other opinions. Thanks and regards!

Figure: 1

The instructions for the course forum, "Your Discussions" to encourage active contributions in the foreign language

Secondly, the course chat, presented as synchronous interaction for learners, allowed participants to have a more real contact with each other. The times and dates planned for the voluntary chat to take place were previously posted on the notice board forum to inform learners. Although the chat could be presented as a resource for exchanging instant questions, suggestions or for just practicing the foreign language expression, it must be said that the distance learners of EASW did not actively participate in this interactive tool. Only twelve of eighty students involved themselves on this voluntary instant medium so that the chat task will be reconsidered as a smaller group exercise so that it could be promoted as a successful discursive tool in a future online course. The instructor may also present the chat as a tool for social interaction and small group work contributions before a collaborative task is finally delivered on the online platform.

\section{Students' Metacognitive Interaction}

The tasks designed for the autonomous distance learning scenarios have motivated critical thinking linked to these learners' professional field. As a result, students' thoughts have highlighted what they know about a particular topic so that they have applied their ideas to a more practical approach that has aimed to find some solutions to different anticipated problems they may find in their profession. This reflective contextualization has proved to be efficient in this ESP learning community. Although some of these metacognitive tasks have been accomplished in autonomous learning environments, they would be more enriching when deliberately proposed in interactive online environments such as discussion 
forums or synchronous chats (Kyei-Blanson \& Donnelly, 2014). These students' metacognitive abilities have demanded an active participation by learners and active intensive observation by teachers so that knowledge building and communication take place in each learner.

The tasks designed for monitoring students' learning progress during the course were divided into three. The first corresponded with the contents of units 1 and 2, while activity 2 dealt with units 3 and 4 (see Figure 2). As a result units 5 and 6 were conveyed with the completion of task 3 . These activities were designed to correspond with the performance of different language skills such as reading or listening comprehension, grammar and use of English, oral and written expression, and vocabulary. Activity 2, for instance, although individually created, demanded the combination of PPP, TBLL and PBL learning strategies since one of its exercises required the video recording of an oral presentation in which students had to answer some questions related to the course, which would additionally involve further research. The tool suggested for this video recording was YouTube or Present me so that they could send the video link for the task to be assessed.

In view of the TBLL, PPP and the PBL strategies, the u-learning tools that have contributed to enhance communicative competences in EFL and interaction among students and between students and the teacher in a distance learning environment have been the video lectures, the PowerPoint Presentations, the wiki, the online glossary, the course chat, and the discussion forum. Table 1 illustrates a clearer classification of tasks according to the learning outline used.

Table: 1

Interactive learning approaches for distance learning tasks

\begin{tabular}{lll}
\hline English Applied to Social Work & \\
\hline TBLL & PPP & PBL \\
\hline $\begin{array}{l}\text { Individual tasks to } \\
\text { hand in }\end{array}$ & $\begin{array}{l}\text { Video lectures / } \\
\text { presentations } \\
\text { Interactive } \\
\text { exercises }\end{array}$ & $\begin{array}{l}\text { Wiki (not used in these } \\
\text { distance courses yet). } \\
\text { Discussion Forums } \\
\text { definitions and } \\
\text { examples in context }\end{array}$ \\
\hline $\begin{array}{l}\text { Creation of exam } \\
\text { questions with 4 } \\
\text { options and only 1 } \\
\text { is correct }\end{array}$ & $\begin{array}{l}\text { PDF documents with } \\
\text { further explanations }\end{array}$ & $\begin{array}{l}\text { PowerPoint } \\
\text { Presentations by } \\
\text { students responding to } \\
\text { a question delivered by } \\
\text { the teacher }\end{array}$ \\
\hline $\begin{array}{l}\text { External links for } \\
\text { practicing listening, } \\
\text { pronunciation, } \\
\text { grammar, reading } \\
\text { or writing skills }\end{array}$ & $\begin{array}{l}\text { PowerPoint } \\
\text { Presentations by } \\
\text { students responding to a a } \\
\text { question delivered by } \\
\text { the teacher }\end{array}$ & $\begin{array}{l}\text { Posting of exam } \\
\text { question examples on } \\
\text { the course forum to } \\
\text { share with other } \\
\text { distance learners }\end{array}$ \\
\hline
\end{tabular}

Although individually addressed, task 3 was also designed with the intention of using the EFL skills and a real-life problem solving (Beldarrain, 2006, p.147) with clear objectives, instructions and resources (See figure 3).Task 3 was presented as an example of exercises planned for students to accomplish, individually, the three strategies proposed for learning: PPP, TBLL and PBL. It had some listening exercises, reading, vocabulary, use of English and writing skills since students had to find out information about the two prisons in Gran Canaria, and how social workers would communicate with the inmates, their families and the professionals working in these institutions. Although these three strategies may depend on group work, the distance learners only presented their projects or tasks individually and there was not a chance for working in small groups as the TBLL or PBL would demand. 


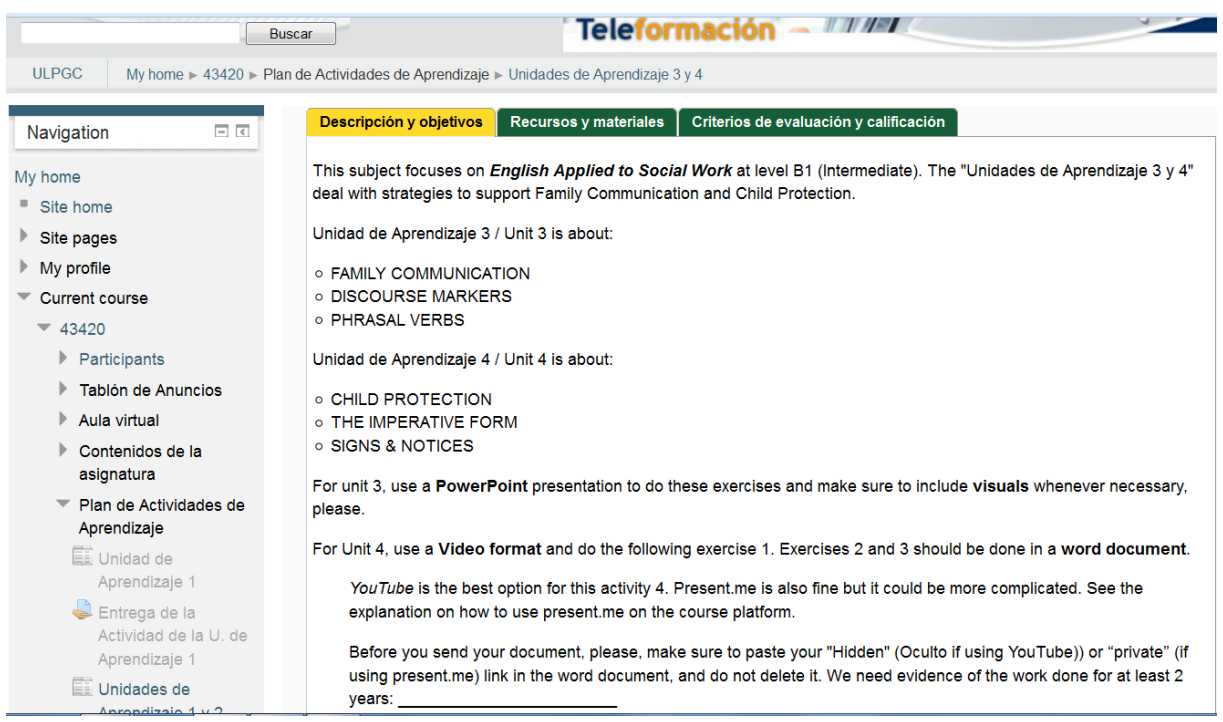

Figure: 2

Description and objectives for task 2.
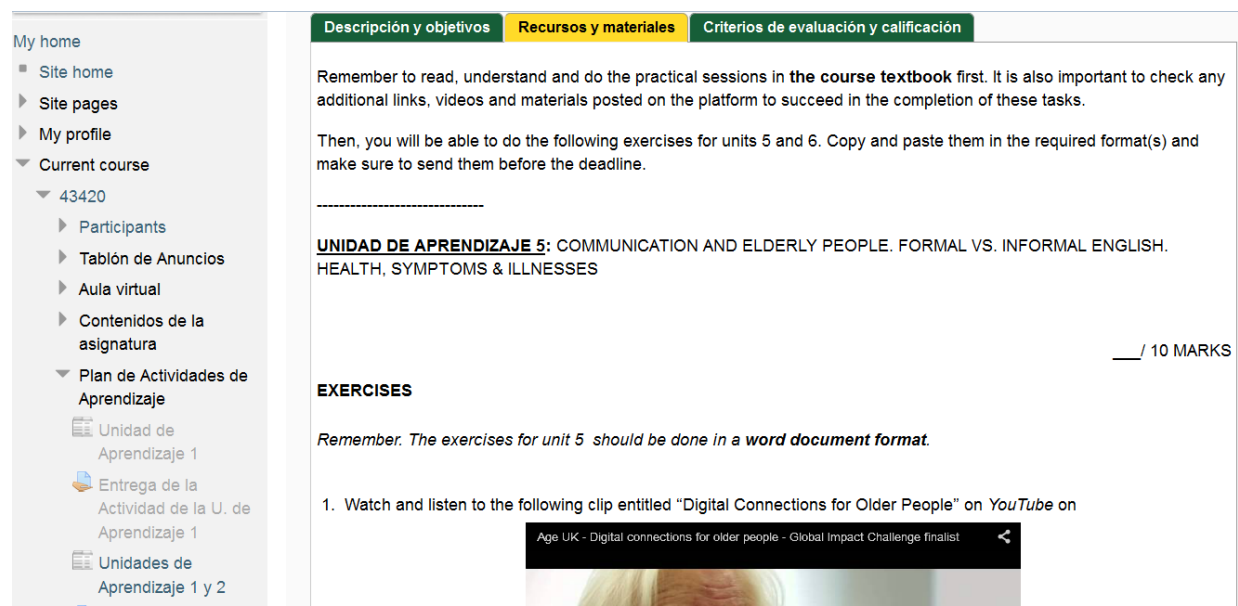

Figure: 3

Resources and materials for task 3 (Units 5 and 6).

(In) Formative, Summative and Internet-based Assessment

The plan of this course was created considering the core content, the interaction happening among the educational community and the correspondence between tasks and the assessment criteria. In this line, assessment was adaptive, formative, summative, informative, interactive, internet-based and progressive (Griffin, 2014; Griffin et al., 2010; Zafar \& Albidewi 2015) since students were offered suggestions to improve their work and feedback on the good practice and common mistakes they provided in each task. The evaluation of EASW was designed following the rules proposed by the Teleformación organization at ULPGC so that the formative and summative assessment was especially individually-oriented. Students participated in a formative, summative and internet-based assessment that was also personalized and instant or almost quite short at the time of providing feedback or suggestions for improving learners' work.

The formative evaluation of EASW had two obligatory items with a summative percentage of 50 each: the completion of the tasks and the final exam. The first item of the formative assessment was the accomplishment of the 3 online tasks designed for each unit of the course so that students could demonstrate an adequate understanding of the content studied in the course. The teacher could mark these tasks and intervene in the students' progress with some suggestions for improvement if the activity was sent during the first 
week of the evaluation period. This requires saying that each task was meant to be presented in a two-week period. Learners who sent the activity in the first week had the chance for a second correction, after having followed the suggestions provided by their teacher. This feedback was informative, individual, interactive, interventionist and progressive and it aimed at highlighting the weaknesses and strengths of each student. The final exam was the second item that fulfilled the other remaining $50 \%$ of the evaluation. It consisted of a multiple choice test of 30 questions corresponding with the 6 units of the course, and only one answer being correct. This test was previously designed on the course platform, following the rules of Teleformación, which implied, for instance having a minimum of 3 questions per unit that could be related to lexis, use of English and the reading exercises and syllabus studied in the course. Once the exam was created and accepted by the evaluation committee of the online Degree in Social Work, it was ready for the teacher to print it out and bring it to the face-to-face exam session on the date set for it. Distance learners had to physically sit at the Universidad de Las Palmas de Gran Canaria, if they lived near their campuses, or in any other official institution planned for sitting exams at Teleformación all over Spain.

Another rule of Teleformación established that no questions or comments would be provided by any teacher monitoring an exam, so that all learners in different spaces would have exactly the same conditions. Once the exams were finished, they were delivered to the secretary of Teleformación and sent online to the teacher in charge in 24 or 48 hours. The internet-based assessment offered that the exam marks were posted on the students' personal assessment profile with the number of correct answers, incorrect answers and items not completed. If students had 1 answer wrong they were penalized with 0.33 marks. Figure 4 shows the teacher's access to the assessment corresponding to all students with their marks for their three tasks (See columns UA02, UA04 and UA06), the average mark of the tasks (Media de Act.), the exam mark (EXAMORD), and the final grade (See last column for "Cal.ORD") corresponding to $50 \%$ for the tasks + $50 \%$ for the exam.

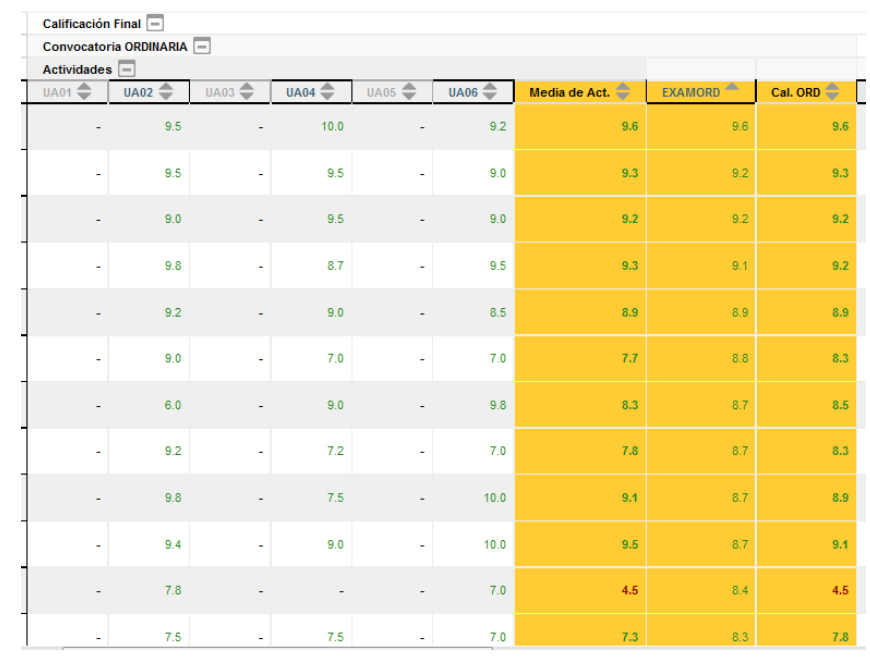

Figure: 4

The teacher's access to the assessment report

This study reveals that advances in assessing students' performance either individually or in groups, together with their communicative competence have positive implications when delivering online courses due to technological resources and appropriate learning methodologies. The possibilities of having more interactive tasks to allow online learners to participate and exchange knowledge anywhere and at any time would improve the necessary communicative skills when learning EFL. Clearly, it is worth mentioning to underline that reexamining the adequate selection of tasks that best correspond with the proper technological tools would make the active learning process easier to flow so that successful communication in EFL takes place. Finally, the results also bring to light that 
another arrangement that deals with tasks and assessment is also essential to improve interaction and the communicative competence in an EFL online course (Gikandi, Morrow \& David, 2011; Hewson, 2012). Either way, tasks, tools and competences should be positioned in the same box when designing any EFL course that especially aims at improving interactive, digital and communicative skills.

Distance EFL educators must adapt their courses to their learners' needs by paying attention to emerging technologies that can improve their communicative skills in the foreign language (Beldarrain, 2006, p.146). Equally, the combination of distance learning courses and English language learning can be a hard endeavor for some learners. This may imply that successful educators should also encourage EFL learners' motivation to work online since teachers often have a significant influence on learners' progress (Craft, Chappell \& Twining, 2008; McEown \& Takeuchi, 2014). Distance EFL teachers ought to also revise how their courses are delivered, how learners' tasks are designed, how distance learners are performing the course abilities, and how assessment is corresponding with students' progress. Moreover, distance EFL educators must innovatively adjust their course design to the most appropriate learning theories and metacognitive strategies that best correspond with a specific task or with learners' needs to successfully achieve the course goals.

\section{SOLUTIONS AND RECOMMENDATIONS}

We have aimed to establish interactive learning approaches in this study based on TBLL, PPP and PBL but they have been mainly oriented for autonomous learning, with the exception of the discussion forums, the glossary and the creation of exam questions. Cooperative and even collaborative learning approaches can be applied in this study by means of designing tasks that can be clearly dependent on the small group participation. In this line, it would be positive to use, the Wiki tool and/or some collaborative video presentations (without having in mind their local areas) with clear instructions for each member to make their contribution in a well-structured group whose aim is to accomplish the goals of the cooperative work. In this line, the interactive experience between groups would improve cognitive, metacognitive, communicative and social skills. This group work could be considered part of the summative assessment describing the minimum aims each member of the group should accomplish.

The chat can also be part of the summative assessment if the teacher would establish clear instructions, specific dates and times for the small groups to exchange information, to discuss their projects and to establish some dialogues in English with the intention of creating their collaborative task. This interaction can also be added to the summative and formative evaluation so that the teacher can contemplate learners' coordination and group work by accessing the chat once the activity is completed. This will have a positive result since not only students' group work but also their communicative skills would be assessed when participating on the chat. Some general feedback regarding good practice and common mistakes could be provided once all the groups interact on their chat.

\section{CONCLUSIONS AND FUTURE RESEARCH DIRECTIONS}

Currently, distance learning courses should be designed for building interaction among the educational members of the community. Online courses should not only be individuallyoriented, personalized and context-aware in order to answer learners' specific needs but they ought to be collaboratively-oriented in order to enrich the social, communicative and interactive abilities of its participants. Learning English as a Foreign Language (EFL) implies long-term interaction between students and teachers, and regular access to information by means of ubiquitous learning (u-learning) environments. Since being an EFL learner is characterized by communicating with others, it is also beneficial to build knowledge together in interactive learning scenarios. Because today's learners often use the internet for different purposes, and that includes for socially contacting their online friends, EFL distance learners at the Universidad de Las Palmas de Gran Canaria unsurprisingly demand more participation in discussion forums 
and in online spaces where they can use their metacognitive communicative skills when interacting with others. This is advantageous when applied to EFL courses that are focused on enhancing the communicative competence of their learners.

In order to deal with the performance and the assessment of communicative competences in $\mathrm{EFL}$, a revision of current pedagogical strategies for distance learning spaces have been initially discussed in this paper. Secondly, it has been highlighted that the achievement of appropriate interactive tasks should correspond with the communicative language skills learners are performing. Finally, the internet-based assessment of the distance learning course has been typified for being formative, summative, interventionist, informative, interactive and progressive (Griffin, 2014; Griffin et al., 2010).

This study highlights that due to appropriate u-learning tools, distance learning participants are given flexibility to complete the required tasks at the best time and in the best place they choose to access their online courses. Nowadays, distance learning communities are immersed in a variety of interactive digital spaces, which can be advantageous as they can be accessed from any mobile device, by means of internet access and a u-learning methodology. English Applied to Social Work, in a distance learning environment has proved that using various online tools that are combined with competence-performance and interactive tasks can favor contextualized ubiquitous EFL learning. This is an advantage for today's citizens that are constantly updating their education with ICT-supported courses. Further research should be pervasive in order to allow current citizens' abilities to be professionally and personally adapted to the most demanding desires of an open-learning society that is constantly moving forward.

Some future directions to further continue this ubiquitous learning analysis would be related to collaborative learning in online distance learning courses. Learners' immersion in technology, for their own individual and collaborative learning process, ought to be combined with multiple real-life scenarios that participate in a communicative approach for EFL distance learners. Since technology is changing daily, empirical research on current technologies that enhance not only students' interaction but their adaptation to the newest digital learning spaces could also be another research point.

Equally, autonomous learning and individual /cooperative/collaboratively students' creativity by means of online distance learning environments could be an area of additional research (Loveless, 2007) since the active involvement of learners makes the best learning happen. Learning is metacognitive and non-stop. Every learner should think about thinking and revisit the knowledge that has already transformed society. Everyone's awareness of that learning is always exclusive and it can provide new insights of understanding.

\title{
BIODATA and CONTACT ADDRESSES of the AUTHOR
}

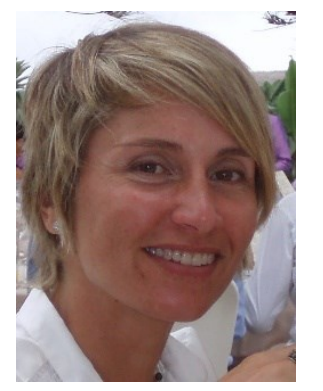

Dr. Soraya GARCIA-SANCHEZ is an Associate Professor at the Department of Modern Languages (English) of the Universidad de Las Palmas de Gran Canaria (ULPGC), where she has been teaching language, culture and literature courses both online and on a face-toface basis. Soraya's research areas are focused on e-learning and ubiquitous learning environments for EFL students at university level, and on women's writing and literature in contemporary contexts.

\author{
Dr. Soraya GARCIA-SANCHEZ \\ Universidad de Las Palmas de Gran Canaria \\ Campus Universitario de Tafira $\mathbf{S} / \mathbf{N}$ \\ Edificio de Ingenierias, 35016 \\ Despacho 3 (Módulo F), SPAIN \\ Phone: (+34) 928458608 \\ e-Mail: soraya.garcia@ulpgc.es
}




\section{REFERENCES}

Adair-Hauck,B., \& Troyan, F. J. (2013). A descriptive and co-constructive approach to integrated performance assessment feedback. Foreign Language Annals, 46(1), 23-44.

Andersen, R., \& Ponti, M. (2014). Participatory pedagogy in an open educational course: Challenges and opportunities. Distance Education, 35, 234-249.

Beldarrain, Y. (2006). Distance education trends: Integrating new technologies to foster student interaction and collaboration. Distance Education, 27(2), 139-153.

Burbules, N. (2012). El aprendizaje ubicuo y el futuro de la enseñanza". Encounters 13, 314. Retrieved from http://library.queensu.ca/ojs/index.php/encounters/ article/view/4472/4513

Canale, M., \& Swain, M. (1980). Theoretical bases of communicative approaches to second languages teaching and testing. Applied Linguistics, 1, 1-47.

Cancino, M. (2015). Assessing learning opportunities in EFL classroom interaction: What can conversation analysis tell us? RELC Journal. A Journal of Language Teaching and Research, 1(1), 1-15.

Chen, C.M., Lee, H.M., \& Chen, Y.H. (2005). Personalized e-learning system using Item Response Theory. Computers \& Education, 44(3), 237-255.

Cope, B., \& Kalantzis, M. (Eds.) (2010). Ubiquitous learning. Urbana and Chicago: University of Illinois Press.

Chenol Mora, A. (2013). El aprendizaje ubicuo desde una perspectiva de la adquisición de lenguas extranjeras: un ejemplo practico de un curso E/LE. Foro de Profesores de $E / L E$, 9, 29-38. Retrieved from http://www.foroele.es/revista/index.php/ foroele/article/view/198/196

Craft, A., Chappell, K., \& Twining, P. (2008). Learners reconceptualising education: Widening participation through creative engagement? Innovations in Education and Teaching International, 45(3), 235-245.

Criado, R. (2013). A critical review of the Presentation-Practice-Production Model (PPP) in Foreign Language Teaching. In R. Monroy (Ed.), Homenaje a Francisco Gutiérrez Diez (pp. 97-115). Murcia: Edit.um.

De la Torre Cantero, J., et al. (2013). Entorno de aprendizaje ubicuo con realidad aumentada y tabletas para estimular la comprensión del espacio tridimensional. RED, Revista de Educación a Distancia. Número 37. Número especial dedicado a "Aprendizaje ubicuo", Retrieved from http://www.um.es/ead/red/37

Ellis, R. (2003). Task-based Language Learning and Teaching. Oxford, New York: Oxford.

Garcia Aretio, L. (2014). Bases, mediaciones y futuro de la educación a distancia en la sociedad digital. Madrid: Sintesis.

Garcia-Sanchez, S. (2014). Knowledge creation and digital collaboration in higher education". In S. Rutherford (Ed.), Collaborative Learning: Theory, Strategies and Educational Benefits (pp.1-14). New York: Nova Science Publishers. 
Garcia-Sanchez, S. (2012). English in class and on the go: Multimodal u-learning. The Eurocall review, 20(2), 94-102.

Garcia-Sanchez, S., Guerra-Artal, C., \& Afonso-Suarez, M. D. (2012). Ubiquitous learning and Prometeo for English language learners. Ubiquitous Learning: An International Journal, 4(1), 65-76.

Gikandi, J. W., Morrow, D., \& Davis, N. E. (2011). Online formative assessment in higher education: A review of the literature. Computers \& Education, 5 $\pi(4), 2333-2351$.

Griffin, P. (Ed.). (2014). Assessment for teaching. Cambridge University Press.

Griffin, P., Murray, L., Care, E., Thomas, A., \& Perri, P. (2010). Developmental assessment: Lifting literacy through professional learning teams. Assessment in Education:

Principles, Policy \& Practice, 17(4), 383-397.

Harmer, J. (2009). How to Teach. (5 ${ }^{\text {th }}$ ed). Harlow. Longman.

Harmer, J. (1996). Is PPP dead? Modern English Teacher, 5(2), 7-14.

Hewson, C. (2012). Can online course-based assessment methods be fair and equitable? Relationships between students' preferences and performance within online and offline assessments. Journal of Computer Assisted Learning, 28(5), 488-498.

Imtiaz, M. A., \& Maarop, N. (2014). A review of technology acceptance studies in the field of education. Jurnal Teknologi, 69(2), 27-32. http://dx.doi.org/10.11113/ jt.v69.3101

Jones, N., Chew E., \& Blackey H. (2014). A classroom without walls? The institutional policy for social software in learning, teaching and assessment. International Journal of Innovation and Learning, 16(4), 417-427.

Kalantzis, M., \& Cope, B. (2012). New Learning: Elements of a Science of Education. Cambridge: Cambridge University Press.

Kyei-Blankson, L., \& Donnelly, H. (2014). Interaction and presence as important elements in student learning in online environments. In Proceedings of World Conference on E-Learning in Corporate, Government, Healthcare, and Higher Education 2014 (pp. 1055-1058). Chesapeake, VA: Association for the Advancement of Computing in Education (AACE).

Liu, G.Z., \& Hwang, G.J. (2009). A key step to understanding paradigm shifts in elearning: Towards context-aware ubiquitous learning. British Journal of Educational Technology, 41(2), E1-E9. doi:10.1111/j.1467-8535.2009.00976.x

Liu, G.Z., Hwang, G.J., Kuo, Y.L., \& Lee, C.Y. (2014). Designing dynamic English: A creative reading system in a context-aware fitness centre using a Smart phone and QR codes. Digital Creativity, 25(2), 169-186.

Martin-Santana, C., \& Garcia-Sanchez, S. (2014). Nivel B1: Autonomia y trabajo de los estudiantes de primer año de EFL. In C.M. Travieso Gonzalez, J.M. Canino Rodriguez \& J.B. Alonso Hernandez (Ed.), Libro de Actas de las I Jornadas Iberoamericanas de Innovación Educativa en el ambito de las TIC (pp.41-50). Las Palmas de Gran Canaria: Universidad de Las Palmas de Gran Canaria. 
McEown, M. S., \& Takeuchi, O. (2014). Motivational strategies in EFL classrooms: how do teachers impact students' motivation? Innovation in Language Learning and Teaching, $8(1)$, 20-38. doi:10.1080/17501229.2012.741133

Loveless, A. (2007). Creativity, new technologies and learning: An update. Futurelab, Bristol.

Ogata, H., \& Uosaki, N. (2012). A new trend of mobile and ubiquitous learning research: Towards enhancing ubiquitous learning experiences. International Journal of Mobile Learning and Organisation, 6(1), 64-78.

Pennings, H.J.M., et al. (2014). Real-time teacher-student interactions: A dynamic systems approach. Teaching and Teacher Education, 37, 183-193. Retrieved from http://www.sciencedirect.com/science/article/pii/S0742051X13001303

Pirsl, D., Popovska, S., \& Pirsl, T. (2013). Critical thinking, autonomous learning and metacognitive strategies in ESP Science Teaching. International Journal of Scientific Engineering and Research, 1(2), 1-6. https: //www.academia.edu/5320763/Critical_Thinking_Autonomous_Learning_ and_Metacognitive_Strategies_in_ESP_Science_Teaching

Price, S., \& Rogers, Y. (2004). Let's get physical: The Learning benefits of interacting in digitally augmented physical spaces. Computers \& Education, 43, 137-151.

Psotka, J. (2012). Interactive learning environments and games. Interactive Learning Environments, 20(4), 309-310.

Spector, J. M. (2014). Emerging educational technologies: Tensions and synergy. Journal of King Saud University-Computer and Information Sciences, 26(1), 5-10.

Taraghi, B. (2012). Ubiquitous personal learning environment. International Journal of Emerging Technologies in Learning, $7(2), 7-14$.

Traore, M., \& Kyei-Blankson, L. (2011). Using literature and multiple technologies in ESL Instruction. Journal of Language Teaching and Research, 2(3), 561-568. doi:10.4304/jltr.2.3.561-568

Vizoso Martin,C. (2013). Los MOOCs un estilo de educación 3.0.". SCOPEO INFORME No2: MOOC: Estado de la situación actual, posibilidades, retos y futuro (pp. 239-231). Retrieved from http://scopeo.usal.es/wp-content/uploads/2013 /06/scopeoi002.pdf.

Wurst, C., Smarkola, C., \& Gaffney, M.A. (2008). Ubiquitous laptop usage in higher education: Effects on student achievement, student satisfaction, and constructivist measures in honors and traditional classrooms. Computers \& Education, 51(4), 1766-1783.

Zafar, A., \& Albidewi, I. (2015). Evaluation study of eLGuide: A framework for adaptive elearning. Computer Applications in Engineering Education, 23(1), 542-555. doi: 10.1002/cae.21625

\section{ADDITIONAL READINGS}

Abachi, H.R., \& Muhammad, G. (2014). The impact of m-learning technology on students and educators. Computers in human behavior, 30, 491-496.

doi:10.1016/j.chb.2013.06.018. 
AbuSeileek, A. F. (2012). The effect of computer-assisted cooperative learning methods and group size on the EFL learners' achievement in communication skills. Computers \& Education, 58(1), 231-239.

Ayoola, O. L., \& Mangina, E. (2014). Personalisation of a U-Learning Environment for Third Level Education. Yüksekögrretim Dergisi, 4(1), 54-60.

Bergmann, J., \& Sams, A. (2012). Flip your classroom: Reach every student in every class every day. Eugene: OR: ISTE.

Choi, J.H., Kim, G., \& Lee, J.Y. (2012). Assessment Criteria for Verbal Interaction Contents in r-Learning. IJREA; International Journal of Robots, Education and Art, 2(1), 16-29.

Coombe, C., O'Sullivan, B., \& Stoynoff, S. (Eds.). (2012). The Cambridge guide to second language assessment. Cambridge University Press.

Dekhinet, R. (2008). Online enhanced corrective feedback for ESL learners in higher education. Computer Assisted Language Learning, 21(5), 409-425.

DiGiovanni, E., \& Nagaswami, G. (2001). Online peer review: an alternative to face-toface? ELT journal, 55(3), 263-272.

Duran, E. B., Alvarez, M., Unzaga, S., Salazar, N., \& Fernandez Reuter, B. (2014). Desarrollos basados en ontologias de soporte al aprendizaje ubicuo. In XVI Workshop de Investigadores en Ciencias de la Computación.

Garg, A., \& Goel, S. (2013). Autonomous interaction model in ubiquitous learning systems. International Journal of Computer Applications, 70(7), 25-29.

Greenberg, I. (2012). ESL Needs Analysis and Assessment in the Workplace. The Cambridge Guide to Second Language Assessment, 178.

Hegelheimer, V., \& Fisher, D. (2013). Grammar, writing, and technology: A sample technology-supported approach to teaching grammar and improving writing for ESL learners. CALICO journal, 23(2), 257-279.

Jeong, H. Y., \& Choi, H. G. (2012). A design of personalized U-learning system using IRT. JCIT, $\nearrow(6), 268-275$.

Lee, B. G., Kim, S. J., Park, K. C., Kim, S. J., \& Jeong, E. S. (2012). Empirical analysis of learning effectiveness in u-Learning environment with digital textbook. $K S I I$ Transactions on internet and information systems (TIIS), 6(3), 869-885.

Liang, T.H., Huang, Y.M., \& Tsai, C.C. (2012). An Investigation of Teaching and Learning Interaction Factors for the Use of the Interactive Whiteboard Technology. Educational Technology \& Society, 15(4), 356-367.

Little, D. (2005). The Common European Framework and the European Language Portfolio: Involving learners and their judgements in the assessment process. Language Testing, 22(3), 321-336.

Morrison, S. (2002). Interactive Language Learning on the Web. ERIC Digest.

Sappington, T.E. (1984). Creating learning environments conducive to change: the role of fear/safety in the adult learning process. Innovative higher education, 9(1), 1929. 
Sears, D.A., \& Pai, H.H. (2013). Effects of cooperative versus individual study on learning and motivation after reward-removal. The journal of experimental education, 80 , 246-262.

Shawback, M. J., \& Terhune, N. M. (2002). Online interactive courseware: using movies to promote cultural understanding in a CALL environment. ReCALL, 14(01), 85-95.

Shin, D. H., Shin, Y. J., Choo, H., \& Beom, K. (2011). Smartphones as smart pedagogical tools: Implications for smartphones as u-learning devices. Computers in Human Behavior, 27(6), 2207-2214.

Suvorov, R., \& Hegelheimer, V. (2013). Computer-assisted language testing. The Companion to Language Assessment.

Tu, C. H., McIsaac, M., Sujo-Montes, L., \& Armfield, S. (2013). Building mobile social presence for U-learning. Technology Platform Innovations and Forthcoming Trends in Ubiquitous Learning, 77.

Zhao, X., \& Okamoto, T. (2011). Adaptive multimedia content delivery for context-aware u-learning. International Journal of Mobile Learning and Organization, 5(1), 4663.

Zhou, W., Cui, B., Wang, B., Shi, Q., \& Yokoi, S. (2012, July). An exploration of ubiquitous learning in computer fundamental learning scenario. In Computer Science \& Education (ICCSE), 2012 7th International Conference on (pp. 1420-1424). IEEE.

Warschauer, M. (2013). Comparing face-to-face and electronic discussion in the second language classroom. CALICO Journal, 13(2/3), 7-26.

Wu, W. C. V., Yen, L. L., \& Marek, M. (2011). Using online EFL interaction to increase confidence, motivation, and ability. Educational Technology \& Society, 14(3), 118-129. 